\title{
Classroom Teaching Reform Based on the Quality of Personnel Training
}

\author{
Zhang Xingfu \\ Academic Affairs Office \\ Jiamusi University \\ Jiamusi, Heilongjiang 154007 \\ 292587870@qq.com \\ Ma Xiaojun* \\ School of Mechanical Engineering \\ Jiamusi University \\ Jiamusi, Heilongjiang 154007 \\ mjzx2009phd@163.com
}

\author{
Yang Abin \\ Employment Office \\ Jiamusi University \\ Jiamusi, Heilongjiang 154007
}

\author{
Li Chunjiang \\ Academic Affairs Office \\ Jiamusi University \\ Jiamusi, Heilongjiang 154007
}

\begin{abstract}
Most of the local comprehensive universities belong to the teaching and research university, their training goal is basically to cultivate "high quality, application-oriented" talent, lead the innovation of educational idea and mode with information technology, realize the deep integration of modern information technology and classroom teaching. Take Jiamusi University as an example, to realize classroom teaching reform, it makes full use of school's quality education resources, and draws on others successful experience. The school adopts flexible teaching methods and means, and reasonably arranges teaching content based on the curriculum syllabus, using classroom teaching methods such as case, exploration and project teaching. It changes the assessment methods, enriches students' discipline vision, and stimulates students' endogenous motivation to enhance the quality of personnel training.
\end{abstract}

Keywords-classroom teaching; teaching reform; training quality; teaching method

\section{INTRODUCTION}

"Teaching quality is the lifeline", classroom teaching reform is an important measure to deepen the reform of higher education, improve the quality of education. At present, colleges and universities are actively exploring the MOOC, network courses, formative assessment courses, boutique resources common courses and other high-quality course construction. The school promotes classroom teaching reform through classroom construction, and promotes deep integration of informatization and classroom with information technology to realize the innovation of education ideas and mode. It is an important task of the development and construction of colleges and universities. In order to achieve effective classroom teaching, in the teaching process of colleges and universities, teachers carry out teaching activity based on syllabus, such as curriculum design, preparation of teaching plans, selection of teaching materials, lesson preparation, setting homework, designing topics, examination assignment and performance analysis. They develop curriculum syllabus scientifically and

Fund project: the education and teaching research program of Jiamusi University: (2016JW10092017LGL-007)

*Correspondence Author: Ma Xiaojun(1976-),master tutor strictly implement it, and constantly update the teaching content. In the arrangement of teaching content, it reflects classified training. The school promotes the deep integration of scientific achievements of teachers and classroom teaching, and the diversification of classroom teaching methods to enrich students' learning method, broadens their discipline vision. At the same time, the school improves teaching method and formative assessment-oriented diversified assessment methods, strengthen the construction of examination discipline, which are the important measures of classroom teaching reform. It is the inevitable requirement of higher teaching reform to deepen classroom teaching reform, comprehensively improve the quality of classroom teaching, and improve the quality of personnel training.

\section{STRENGTHEN THE DEVELOPMENT AND IMPLEMENTATION OF COURSE OUTLINE AND CONTENT}

\section{A. Develop course outline scientifically and rationally}

Starting from the training objectives, the development and revision of course outline reflects the new educational ideas. It uses advanced teaching methods, and actively absorbs the classic teaching content and reflects the latest research results. It pays attention to the organic connection of course content, and has clear requirements and highlights. First, it is in line with the school orientation and personnel training objectives, aiming to achieve "coordinated development of knowledge, ability and quality"; second, it reflects the spirit of teaching reform, make innovations in curriculum content, teaching methods, teaching link arrangements, highlighting the training of students' independent learning ability and innovation ability; Third, it integrates socialist core values into the classroom, update the course content and integrate the frontier knowledge by combining the professional characteristics and development of science and technology; fourth, it adheres to the principle of linking theory with practice and speaking concisely and practicing frequently, constantly updates and optimizes practice teaching content, strengthens the practice of students' practical 
ability training, trains students' innovative thinking and innovation ability.

\section{B. Reflect classified training in the arrangement of teaching content}

For the training of innovative talents such as "excellent engineer", "excellent doctor" and "excellent teacher", when ensuring the teaching of basic knowledge, integrate subject frontier knowledge, introduce project teaching method, and include teachers' research method and results into the teaching content, encourage students to participate in teachers' scientific research projects. At the same time, declare national, provincial and school-level students innovative entrepreneurship training program, principals innovation and entrepreneurship fund projects, school youth league college students scientific and technological innovation projects, so that students have a certain scientific research background and corresponding ability of scientific research and innovation. For the cultivation of high-quality applied talents, strengthen the practice links to increase the content of practical teaching, train students' ability to use learned knowledge to analyze and solve problem. Encourage teachers to carry out research teaching, case teaching, and heuristic teaching, promote students to conduct independent learning, learning group collaborative learning and other learning methods.

\section{Student-Centered, Improved Teaching Methods, AND LET SCIENTIFIC RESEARCH NURTURE TEACHING}

\section{A. Promote the deep integration of teachers' research results and classroom teaching}

Teachers all have their own research areas and academic expertise. In undergraduate teaching, teachers can combine the characteristics of course, and timely integrate their scientific research results into teaching, introduce project teaching methods, so as to achieve the transformation of scientific research to teaching, and achieve good teaching results. There are mainly six ways to let scientific research nurture teaching: first, teachers distribute the frontier scientific and technological knowledge to students through academic reporting activities; second, the undergraduate students enter the laboratory in advance to participate in teachers' research projects and various innovative entrepreneurship training program, science and technology innovation projects held by students; third, graduation thesis (design) topics are derived from teachers' research projects; fourth, integrate the teachers' research results directly into the classroom or teaching materials; fifth, teachers develop experimental teaching device; sixth, select and simplify scientific research topics as open experiments. The "teaching method of optimizing the class, strengthening the extracurricular" gives full play to the promotion of scientific research on innovative talents training. It is conductive to the training of students' overall quality, innovative quality and cooperative spirit.

\section{B. Students-centered, promote the diversification of classroom teaching methods}

Flexibly use a variety of teaching methods to encourage students to study independently. On the basis of the traditional teaching mode, according to different teaching content, flexibly integrate heuristic, exploratory, discussion-oriented and participatory teaching methods. At the same time, combine the modern multimedia technology with traditional blackboard in an organic way to fully mobilize the enthusiasm of students, explore and carry out formative assessment, conduct openbook examination, promote network examination and other assessment methods to encourage students to study independently. In the course of teaching, many teaching forms are developed, such as the combination of teacher teaching and student group discussions, combination of special report, mutual evaluation of students and teacher reviews, combination of theoretical teaching and case analysis, combination of class teaching and practical training after class, gradually creating a teacher-led and student-centered heuristic, discussion-oriented classroom teaching atmosphere.

\section{Build the second classroom activity system for college students}

Take students as center, and open experimental project, teacher research project, college students innovation and entrepreneurship training program as platform, integrate project teaching into the second classroom to train students' innovative consciousness and ability of innovation and practice. Around the goal of personnel training, take students as the main body and implement project teaching method. Focus on process training, and encourage students to participate in various competitions through projects, so as to train students' practical ability, improve training quality, and provide quality, knowledge and skill guarantee for students' full employment. Take Jiamusi University as an example. It builds the second class activity system through ideology and politics, scientific and technological competition, innovation and entrepreneurship, social practice, public welfare activities, humanistic activities, artistic activities and sports activities. The second classroom education system is as shown in Fig. 1

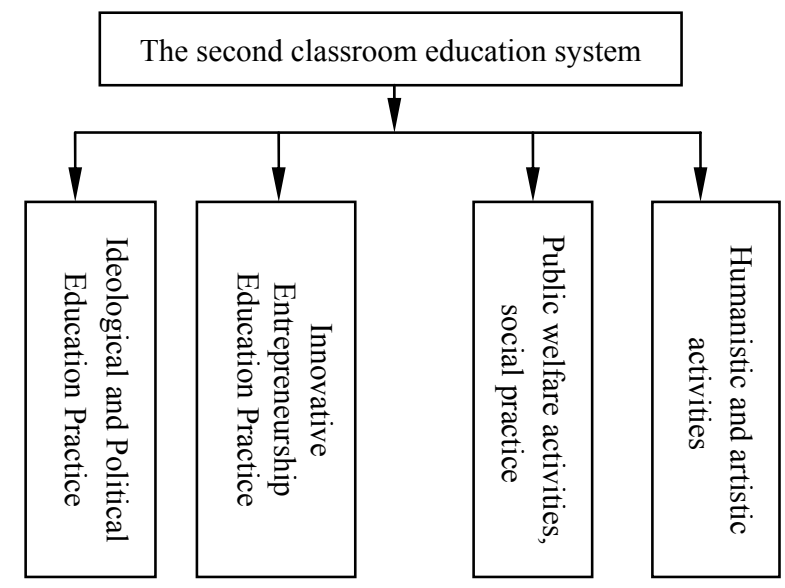

Fig. 1. The second classroom activity system diagram 


\section{STRENGTHEN THE CURRICULUM REFORM, AND IMPROVE STUDENTS' INDEPENDENT LEARNING METHODS}

\section{A. Enrich students' learning methods, and broaden students' discipline vision}

Strengthen the construction of course center's informative condition, take the construction of boutique open courses and hundred courses as the core. Increase the input, actively organize the recording, production and launching of online course, and offer them on course center platform for students to have offline learning. In addition to classroom lectures, provide students a self-learning environment based on network resources. Students can read a large number of professional books and papers as extra-curricular learning according to their own interests. Students participate in teachers' research projects and various innovative entrepreneurship training program, scientific and technological innovation projects and other research, innovative learning. Students conduct practice learning through participation of science and technology competition, and have independent learning under the guidance of instructor. Establish college students innovation and entrepreneurship training base, and fully open the base. Stimulate students' interest in learning through systematic learning and practical training, so as to expand and cultivate the students' multidisciplinary vision, improve students' innovative ability, self-learning ability, and cultivate their team spirit.

\section{B. Strengthen the quality of test papers, and reform examination methods}

Strictly manage the quality of test papers, do all aspects of the examination work well. The form and content of the examination are determined based on the syllabus. Properly handle the relationship of knowledge and ability, theory and practice, highlights and knowledge range. The amount of questions should be moderate with appropriate depth, breadth and difficulty. Carry out flow process when marking papers, and uses standard comment. Not only focus on assessment of students' acquirement of basic concepts, basic theory and basic skills, but also assess students' ability to apply learned knowledge in an integrated way to analyze and solve problems.

Play the promotion role of formative assessment, carry out formative assessment, and pay attention to course cultivation, so as to enhance the training quality of students. Carry out open-book examination to comprehensively assess the depth and breadth of students' knowledge, train students' comprehensive ability and quality, open thinking. Promote network based examinations. In order to further strengthen the standardization of the examination, establish network question bank and test evaluation platform. On the basis of carrying out network based examination in public courses, computer foundation courses and public foreign language courses, further promote the network based examination of other courses.

\section{REFERENCES}

[1] Ding Mingxiu.Study on the Teaching Reform of Chinese Modern Literature Course Based on the Cultivation of Applied Talents [J]. Journal of Changchun Education College, 2016,(11):41-43.

[2] Ge Chengjun, Yu Huamei, Wang Xu, Huang Yuehua. Exploration on Practice Teaching Reform of Environmental Science Based on the Training of Application-oriented Top-notch Innovative Talents [J]. China Off- campus Education.

[3] Li Wenya. Exploration on Teaching Reform of Architectural Decoration Design with the Purpose of Work Process and Job Capacity Training[J]. Weekly Journal, 2016, (26): 36-37.

[4] Guo Ruifeng. Study on Classroom Teaching Reform Strategy Based on Excellent Personnel Training[J]. Journal of Suzhou Education College, 2015, (03): 97-98.

[5] Su Zhiwu. Deepen Classroom Teaching Reform to Improve the Quality Of Personnel Training[J]. China Higher Education, 2012, (17): 10-14.

[6] Xie Xiaoyuan, Wu Qingxian. Reform and Practice of Foreign Language Practice Teaching Based on the Goal of Innovative Talents Training[J]. China University Teaching, 2012, (08): 82-85.

[7] Jia Liting. Translation Teaching Reform with the Goal of Practical Talents Training $[\mathrm{J}]$. Northern Literature (The 2nd Issue of the Month), 2010, (05): 40.

[8] Lin Haiping, Zhang Liqin, Zhang Xin, Wang Yongjun, Hu Jiafu. Classroom Teaching Reform of Innovative Application-oriented Talent Training[J]. Microbiology Bulletin, 2009, (12): 1912-1915.

[9] Wang Suyan. Classroom Teaching Reform Based on Innovative Talents Training[J]. Beijing Education (Higher Education Edition), 2009, (11): 44-45.

[10] Mao Xiaoping, Wu Xiaorong.Study on the Classroom Teaching Method of Improving the Cultivation Level of Innovative Talents in Colleges and Universities - Also on the Reform of Classroom Teaching Mode of Ideological and Political Theory Course[J]. Journal of Harbin University, 2008, (10): 129-133. 